\title{
Aerial Application of 2,4-D Plus Picloram for Green Rabbitbrush Control
}

\author{
RAYMOND A. EVANS AND JAMES A. YOUNG
}

Highlight: An aerially applied mixture of 2,4-D and picloram was more effective than 2,4-D alone in controlling green rabbitbrush and big sagebrush in a very droughty big sagebrush/desert needlegrass community. Herbage production had more than doubled by 5 years after the brush stand was reduced. Needleandthread was the only species to increase in density because of brush control, although considerable seed was produced from other perennial grasses. Modification of the seedbed environment is apparently necessary to establish additional desert needlegrass or Indian ricegrass plants.

Our purposes were, first, to determine the effectiveness of aerial application of a mixture of 2,4-D [ (2,4-dichlorophenoxy)acetic acid] and picloram (4-amino-3,5,6-trichloropicolinic acid) for control of green rabbitbrush (Chrysothammus viscidiflorus subspecies viscidiflorus) and big sagebrush (Artemisia tridentata), and second, to compare post-treatment plant succession and herbage production to that on areas untreated or sprayed with 2,4-D alone.

Green rabbitbrush is relatively resistant to application of phenoxy herbicides (Hyder et al., 1962). The successful control of green rabbitbrush with 2,4-D depends on careful timing of application in relation to the stage of growth of the shrub and availability of soil moisture. During dry years in the

\footnotetext{
Authors are range scientists, Agricultural Research Service, U.S. Department of Agriculture, University of Nevada, Renewable Resource Center, Reno.

This study was a cooperative investigation of the Agricultural Research Service, U.S. Department of Agriculture, and the Agricultural Experiment Station, University of Nevada, Reno, Nevada. Journal Series No. 277.

Manuscript received June 14, 1974.
}

arid portions of the Great Basin, it is difficult to control rabbitbrush by applying 2,4-D.

Picloram is a much more effective herbicide than 2,4-D for control of green rabbitbrush (Cook et al., 1965; Tueller and Evans, 1969; Evans et al., 1973). Picloram does not control big sagebrush at the rates and timing necessary for control of green rabbitbrush. Tueller and Evans (1969) determined that a mixture of 2,4-D and picloram effectively controlled mixed stands of both species and extended the period when the herbicides could be applied.

In this investigation, we attempted to extend the previous knowledge of mixtures of 2,4-D and picloram for rabbitbrush control by a) applying the mixture aerially, b) applying the mixture to a plant community with species besides big sagebrush and green rabbitbrush, and c) applying the herbicide mixture in one of the most arid environments where green rabbitbrush occurs.

\section{Methods}

We selected, in 1968, a 10-hectare area at Medell Flat, which is about $35 \mathrm{~km}$ north of Reno, Nev. The area supports big sagebrush plant communities, which contain green rabbitbrush, hop sage (Grayia spinosa), green ephedra (Ephedra viridis), and a few clumps of desert peach (Prunus andersonii). The site was selected because it had, based on information available at the start of the experiment, a perennial grass-dominated understory with sufficient density (2.5 plants $/ \mathrm{m}^{2}$ ) to make use of the environment potential released by controlling the shrubs (Young and Evans, 1974a).

The soils, physiographic position, and relation of the experimental area to other plant communities at Medell Flat are given in detail by Young and Evans (1974a). 


\section{Herbicide Application}

A helicopter was used to apply a mixture of $0.42 \mathrm{~kg} / \mathrm{ha}$ of picloram $+2.5 \mathrm{~kg} /$ ha of $2,4-\mathrm{D}$ in 47 liter/ha of water. At the time of herbicide application, the only picloram available in the quantities required was already mixed with 2,4-D as triethylamino salts. The low-volatile esters of 2,4-D are more effective than the amine for control of big sagebrush (Tueller and Evans, 1969). Therefore, the 2,4-D portion of the mixture consisted of $0.84 \mathrm{~kg} / \mathrm{ha}$ of triethylamine salt and $1.64 \mathrm{~kg} / \mathrm{ha}$ of low-volatile esters.

Herbicide was applied on May 16, 1968. At that time, the current year's shoot growth of green rabbitbrush had reached from 6.0 to $7.5 \mathrm{~cm}$, and the leaves of desert peach plants were fully developed. The soil profile was dry to a depth of $45 \mathrm{~cm}$. Total precipitation $(16.4 \mathrm{~cm})$ and spring precipitation $(4.2 \mathrm{~cm})$ were both low in 1967-68. The previous year (1966-67) had had exceptionally high precipitation $(28.5 \mathrm{~cm})$, and moisture remained available in the profile below the $45-\mathrm{cm}$ level at the time of spraying.

Next to the experimental area, about 1,000 hectares were aerially sprayed during the same week with $3.36 \mathrm{~kg} / \mathrm{ha}$ of low-volatile esters of 2,4-D in $28 \mathrm{liter} / \mathrm{ha}$ of oil.

\section{Sampling}

The 10-hectare experimental area was fenced separately. It was bordered on the west and north by the 1,000-ha area sprayed with 2,4-D. South of the exclosure was a separate pasture, continuously grazed, with no brush control. The eastern exclosure fence was part of the grazing allotment boundary. The adjacent area of the neighboring allotment had been very heavily grazed. We had available a) 10 ha treated with 2,4-D + picloram; b) 1,000 ha treated with 2,4-D; c) several thousand hectares without brush-control treatments, but which had been grazed under the same regime; and d) next to it, an extremely heavily grazed area.

We sampled each of the first three areas in 1968 through 1972 by: a) frequency sampling of herbaceous vegetation, following the procedures of Evans and Love (1957); b) density sampling of perennial grasses with 25 plots, one $\mathrm{m}^{2}$ in area; $\mathrm{c}$ ) density sampling of the woody vegetation with 10 plots 10 by $10 \mathrm{~m}$; and d) clipping twenty $1-\mathrm{m}^{2}$ plots at peak herbage production. The adjacent allotment was sampled in 1972 to compare vegetation under heavy browsing of shrubs.

In 1973, we determined perennial-grass caryopsis production on 50 plots $4 \mathrm{~m}^{2}$ in area, randomly located in the area previously treated with picloram and 2,4-D.

\section{Results}

\section{Brush Control}

The mixture of 2,4-D and picloram was more effective in killing green rabbitbrush than was 2,4-D alone (Table 1). The mixture was also more effective on the other shrub species present, except green ephedra. The relatively poor control of big sagebrush with 2,4-D alone is apparently a result of faulty

Table 1. Percent control of shrubs in 1969,1 year af ter application of 2,4-D, alone or mixed with picloram, and species composition (\%) based on cover before herbicides were applied.

\begin{tabular}{|c|c|c|c|c|c|}
\hline \multirow[b]{2}{*}{ Species } & \multicolumn{2}{|c|}{ 2,4-D } & \multicolumn{2}{|c|}{$2,4-\mathrm{D}+$ picloram } & Control \\
\hline & $\begin{array}{l}\text { Species ce } \\
\text { position }\end{array}$ & Control & $\begin{array}{l}\text { Species co } \\
\text { position }\end{array}$ & $\begin{array}{l}\mathrm{m}- \\
\text { Control }\end{array}$ & $\begin{array}{l}\text { Species com- } \\
1 \text { position }\end{array}$ \\
\hline Green rabbitbrush & 30 & 64 & 44 & 95 & 28 \\
\hline Big sagebrush & 27 & 65 & 42 & 96 & 32 \\
\hline Desert peach & 17 & 15 & 5 & 40 & 22 \\
\hline Green ephedra & 21 & 24 & 7 & 14 & 14 \\
\hline Hop sage & 5 & 100 & 2 & 100 & 4 \\
\hline
\end{tabular}
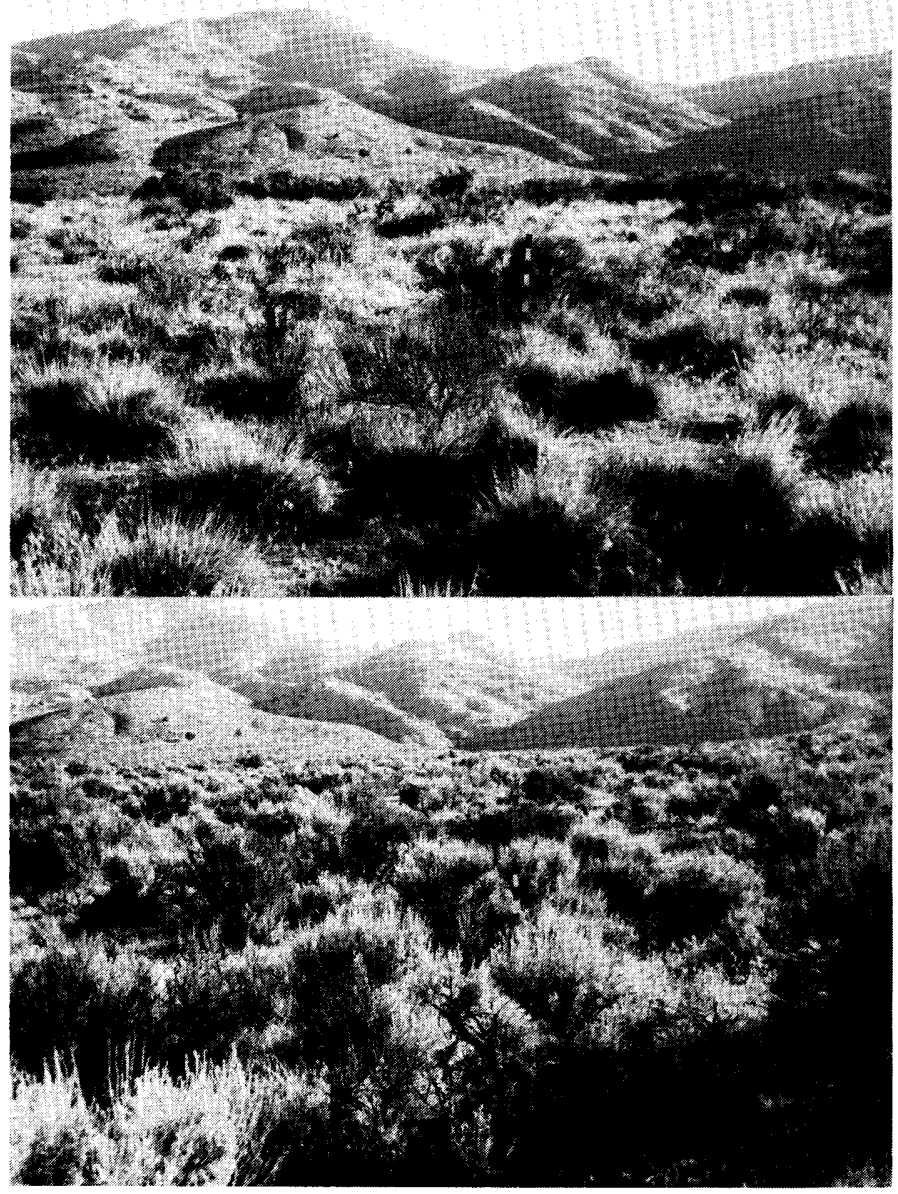

Fig. 1. 2,4-D + picloram treated pasture with native perennial grasses and green ephedra (top) compared with brush-infested control pasture (bottom). Meter stick located in the center of photographs is divided into decimeters.

application equipment and technique (Young and Evans, 1974a). In these communities, hop sage is a desirable browse species that is heavily used. Unfortunatley, either 2,4-D or the mixture of 2,4-D and picloram completely eliminated this species.

Desert peach often increases on western Nevada ranges sprayed with 2,4-D (Young and Evans, 1974a). It has greatly increased in the area of this study sprayed with 2,4-D in 1968. Control of desert peach with 2,4-D and picloram was slightly better than that with 2,4-D alone, but still unsatisfactory. Desert peach has not assumed dominance in the exclosure treated with the mixture of picloram and 2,4-D, apparently because the initial stand density was very sparse before the $40 \%$ reduction resulting from the herbicide treatment (Table $1)$.

The only shrub remaining in the picloram-2,4-D pasture, of sufficient consequence to characterize the modified plant community, was green ephedra (Table 1). The stand of ephedra was reduced more by 2,4-D than by the mixture of 2,4-D + picloram. The 2,4-D alone, which was applied in oil, caused considerably more necrosis of the green leafless stems of green ephedra plants than did 2,4-D + picloram, which were applied in water. The green ephedra-dominated community is visually refreshing in a generally monochromatic vegetation dominated by sagebrush (Fig. 1). The value of green ephedra as a browse species in these communities is controversial. In the control pasture, it was difficult to detect any use of this 
Table 2. Species composition (\% frequency) in 1968 and 1973, and mean composition for 1969 through 1972 , in relation to the application of 2,4-D, 2,4-D + picloram, and control.

\begin{tabular}{|c|c|c|c|c|c|c|c|c|c|}
\hline \multirow[b]{2}{*}{ Species } & \multicolumn{3}{|c|}{ Control } & \multicolumn{3}{|c|}{ 2,4-D } & \multicolumn{3}{|c|}{ Picloram + 2,4-D } \\
\hline & 1968 & $1969-1972$ & 1973 & 1968 & 1969-1972 & 1973 & 1968 & 1969-1972 & 1973 \\
\hline \multicolumn{10}{|l|}{ Annual grasses } \\
\hline Downy brome & 17 & 28 & 51 & 20 & 41 & 53 & 22 & 23 & 34 \\
\hline Sixweeks fescue & 3 & 9 & 11 & 9 & 3 & 2 & 0 & 1 & 1 \\
\hline \multicolumn{10}{|l|}{ Perennial grasses } \\
\hline Needleand thread & 2 & 3 & 1 & 2 & 6 & 9 & 9 & 16 & 18 \\
\hline Desert needlegrass & 5 & 7 & 5 & 8 & 2 & 3 & 18 & 23 & 22 \\
\hline Thurbers needlegrass & 1 & 1 & 1 & 1 & 2 & 2 & 0 & 2 & 3 \\
\hline Squirreltail & 9 & 6 & 7 & 6 & 4 & 5 & 16 & 10 & 9 \\
\hline Indian ricegrass & 2 & 4 & 4 & 1 & 1 & 1 & 4 & 3 & 1 \\
\hline Sandberg bluegrass & 0 & 0 & 0 & 0 & 0 & 0 & 0 & 1 & 1 \\
\hline Annual forbs & 35 & 33 & 3 & 39 & 35 & 24 & 31 & 19 & 8 \\
\hline \multicolumn{10}{|l|}{ Perennial forbs } \\
\hline Spiny skeletonweed & 23 & 19 & 16 & 13 & 6 & 1 & 0 & 2 & 2 \\
\hline Other & 2 & 1 & 2 & 1 & 0 & 0 & 0 & 0 & 1 \\
\hline
\end{tabular}

species. However, in the adjacent allotment where grazing pressure had been more intense, all of the current annual growth of green ephedra was used by cattle. The current annual growth of green ephedra plants that survived the 2,4-D + picloram treatment averaged $180 \%$ of that measured on the control pasture for the period 1969 through 1973.

\section{Herbaceous Vegetation-Species Composition}

The herbaceous vegetation in this community consisted of relatively stable perennial grasses, with downy brome (Bromus tectorum) or ephemeral annual forbs that fluctuated widely in abundance from year to year (Table 2). The ephemeral annual forbs-skunk mimulus (Mimulus nanus) and dwarf monkey flower ( $M$. guttatus)-became the dominant annual flora on dry years such as 1968 (Table 2). During years of average or above precipitation, downy brome dominated the herbaceous vegetation, almost to the exclusion of native annual forbs (Young and Evans, 1974b).

In the 2,4-D-treated pasture, the effect of partial brush control was cxpressed largely by an increasc in annuals (Table 2). Needleandthread (Stipa comata) tended to increase in frequency, but the other perennial grasses remained stable. In the exclosure treated with picloram +2,4-D the increase of needleandthread was more dramatic in the years after the herbicides were sprayed (Table 2). This increase was greater because of the higher initial frequence of perennial grasses and better control of big sagebrush and rabbitbrush. The frequency of annuals in the treated areas with picloram +2,4-D remained relatively stable from 1969 through 1972; even in 1973, a very favorable season for downy brome, this species did not increase as much as it did in the control pasture.

Table 3. Herbage yields $(\mathrm{kg} / \mathrm{ha})$ from control, 2,4-D, and 2,4-D + picloram treatments on pastures from 1968 through $1973 .^{\mathrm{a}}$

\begin{tabular}{cllc}
\hline & & \multicolumn{2}{c}{ Herbage yield } \\
\cline { 2 - 4 } Year & Control & $2,4-\mathrm{D}$ & $2,4-\mathrm{D}+$ picloram \\
\hline 1968 & $170 \mathrm{k}$ & $210 \mathrm{jk}$ & $570 \mathrm{fg}$ \\
1969 & $210 \mathrm{jk}$ & $310 \mathrm{hi}$ & $660 \mathrm{f}$ \\
1970 & $190 \mathrm{k}$ & $520 \mathrm{~g}$ & $930 \mathrm{~d}$ \\
1971 & $240 \mathrm{i}-\mathrm{k}$ & $610 \mathrm{fg}$ & $1,120 \mathrm{c}$ \\
1972 & $180 \mathrm{k}$ & $380 \mathrm{~h}$ & $1,310 \mathrm{~b}$ \\
1973 & $290 \mathrm{~h}-\mathrm{j}$ & $760 \mathrm{e}$ & $1,550 \mathrm{a}$ \\
\hline
\end{tabular}

${ }^{\mathrm{a}}$ Means followed by the same letter are not significantly different at the 0.01 probability level, as determined by Duncan's Multiple-Range Test.

\section{Herbage Yield}

Herbage yield was initially higher in the exclosure treated with picloram and 2,4-D, because we had selected an area that had enough perennial grasses to take advantage of the release in environmental potential expected after brush control (Table 3). The steady increase in herbage production in this exclosure has been more dramatic than changes in herbaceous species composition. Herbage production has increased also in the area treated with 2,4-D, but most of this increase was downy brome. In 1972, when drought limited the establishment and growth of downy brome, total production of this area decreased sharply (Table 3 ).

\section{Perennial-Grass Caryopsis Production}

The key to management of this community, after reduction of brush competition, is increasing the density of perennial grasses. In 1973, an excellent year for grass caryopsis production, slightly more than $8 \mathrm{~kg} / \mathrm{ha}$ of perennial-grass caryopses were produced (Table 4). The maximum number and the heaviest caryopses were produced by needleandthread. In the terminology of range condition and trend, needleandthread is a "decreaser," which falls in density as range condition declines in this environment (Tueller and Blackburn, 1974).

The lack of seedling establishment of perennials, other than needleandthread, in spite of abundant caryopsis production, indicates that seedbed conditions in this community are limiting. The ground cover is very low, with bare granitic soil between the clumps of perennial grasses. Most species cannot germinate on bare soil (Evans and Young, 1974b). Some species overcome the harsh environment of bare seedbeds by

Table 4. Density (number $/ \mathrm{m}^{2}$ ) and weight $(\mathrm{kg} / \mathrm{ha}$ ) of perennial-grass caryopses produced in 1968 and 1973 , on area treated with picloram $+2,4-\mathrm{D}$.

\begin{tabular}{lccccc}
\hline \hline & \multicolumn{2}{c}{ Caryopsis production } & & \multicolumn{2}{c}{ Density } \\
\cline { 2 - 3 } \cline { 5 - 6 } Species & Density & Weight & & 1968 & 1973 \\
\hline Needleandthread & 62 & 3.50 & & 0.6 & 1.1 \\
Desert needlegrass & 55 & 1.50 & & 0.7 & 0.7 \\
Squirreltail & 28 & 0.50 & & 0.7 & 0.7 \\
Indian ricegrass & 46 & 2.60 & & 0.4 & 0.4 \\
Sandberg bluegrass & 16 & 0.03 & & $\mathrm{~T}$ & $\mathrm{~T}$ \\
\hline
\end{tabular}

${ }^{a_{T}}=$ Trace. 
such adaptations as: a) extremely rapid germination, such as is shown by Russian thistle (Salsola iberica) (Evans and Young, 1972a); b) seed mucilage, such as that of tumble mustard (Sisymbrium altissimum) (Young et al., 1970); c) fortuitous burial by ants or rodents, such as occurs to downy brome (LaTourrette et al., 1971); and d) self-burial. Needleandthread is highly adapted by virtue of a needle-like tip of callus and a spiral awn for self-burial.

\section{Significance to Management}

Aerial application of mixtures of 2,4-D + picloram is as effective for control of green rabbitbrush and big sagebrush as previously tested ground applications. The addition of picloram reduces the chance of failure caused by improper timing of application.

By application of herbicides, big sagebrush/green rabbitbrush/desert needlegrass community, growing under very droughty conditions, can be so managed that brush competition is reduced and yield and density of needleandthread is increased. It became clear that, in order to increase the density of other perennial grasses, management must devise a way to modify the potential receptivity of the seedbed. If the stand of perennial grasses is low in density before the brush is controlled, downy brome will preempt the released environmental potential.

\section{Literature Cited}

Cook, C. W., P. D. Leonard, and C. D. Bonham. 1965. Rabbitbrush

\section{Position Open}

\section{UNIVERSITY OF BRITISH COLUMBIA, DEPART- MENT OF ANIMAL SCIENCE}

Range-Pasture Management. Applications are invited for a faculty position at the rank of assistant professor. Candidates should have expertise in the area of animalplant relationships. Responsibilities will include undergraduate and graduate teaching, and the development of a strong research program in the area of specialty.

QUALIFICATIONS: Ph.D. in the area of range-pasture management with strong animal orientation. Emphasis should be on the bioenergetics of grazing livestock - both domestic and wild. The applicant should have proven teaching and research ability. Canadian experience strongly desired. The salary is negotiable, depending on qualifications.

Applications, giving details of curriculum vitae, transcripts, and names of three referees should be forwarded to:

\author{
Dr. W. D. Kitts, \\ Professor and Chairman, \\ Department of Animal Science, \\ University of British Columbia, \\ Vancouver, B.C. V6T 1W5
}

Closing date for applications: July 31, 1975.

Applications are invited from both men and women. competition and control on Utah rangelands. Agr. Exp. Sta., Utah State Univ., Logan. Bull. 454. 28 p.

Evans, R. A., and R. M. Love. 1957. The step-point method of sampling-A practical tool in range research. J. Range Manage. 10:208-212.

Evans, R. A., and J. A. Young. 1972a. Germination and establishment of Salsola in relation to seedbed environment. Part II. Seed distribution, germination, and seedling growth of Salsola and microenvironmental monitoring of the seedbed. Agron. J. 64:219-224.

Evans, R. A., and J. A. Young. 1972b. Microsite requirements for establishment of annual rangeland weeds. Weed Sci. 20:350-356.

Evans, R. A., J. A. Young, and P. T. Tueller. 1973. Current approaches to rabbitbrush control with herbicides. Down to Earth 29(7):1-4.

Hyder, D. N., F. A. Sneva, and V. H. Freed. 1962. Susceptibility of big sagebrush and green rabbitbrush to $2,4-\mathrm{D}$ as related to certain environmental, phenological, and physiological conditions. Weeds 10:288-295.

LaTourrette, J. E., J. A. Young, and R. A. Evans. 1971. Seed dispersal in relation to rodent activities in seral big sagebrush communities. $J$. Range Managc. 24:118-120.

Tueller, P. T., and W. H. Blackburn. 1974. Condition and trend of the big sagebrush/needleandthread habitat type in Nevada. J. Range Manage. 27:36-40.

Tueller, P. T., and R. A. Evans. 1969. Control of green rabbitbrush and big sagebrush with 2,4-D and picloram. Weed Sci. 17:233-235.

Young, J. A., and R. A. Evans. 1974a. Population dynamics of green rabbitbrush. J. Range Manage. 27:127-132.

Young, J. A., and R. A. Evans. 1974b. Downy brome-Intruder in the plant succession of big sagebrush communities in the Great Basin. J. Range Manage. 26:410-415.

Young, J. A., R. A. Evans, R. G. Gifford, and R. E. Eckert, Jr. 1970. Germination of three species of Cruciferae. Weed Sci. 18:41-48.

\section{Range Research Positions Available}

NORTH DAKOTA STATE UNIVERSITY has two range research positions available. These are:

\section{(1) Assistant Botanist (Range Management) \\ (2) Agricultural Research Technician III (Range Management)}

Position (1) is a permanent, continuing professional appointment with the Department of Botany. The individual will be stationed at the Dickinson Experiment Station in southwestern North Dakota. Ph.D. or degree nearing completion required. Salary range $\$ 15,000-\$ 16,000$ per year.

Position (2) is a continuing appointment at the Dickinson Experiment Station as a research technician. B.S. degree required. Salary range $-\$ 9,684-\$ 10,184$ per year.

Applications should include a concise summary of education, experience and other specific qualifications. Three letters of recommendation should accompany the application.

Address all applications and inquiries by August 10 to:

$$
\begin{aligned}
& \text { Warren C. Whitman, Chairman } \\
& \text { Department of Botany } \\
& \text { North Dakota State University } \\
& \text { Fargo, N.D. 58101 } \\
& \text { (Phone: (701) 237-7224) }
\end{aligned}
$$

North Dakota State University is an Equal Opportunity Employer. 